\title{
Seasonal Variation of the Physicochemical and Bacteriological Quality of Water from Five Rural Catchment Areas of Lake Victoria Basin in Kenya
}

\section{Ouma SO*, Ngeranwa JN, Juma KK and Mburu DN}

Department of Biochemistry and Biotechnology, Kenyatta University, Nairobi, Kenya

\begin{abstract}
Seasonal and regional variation of the physicochemical and bacteriological characteristics of 180 water samples collected from five fish landing beaches of Luanda Rombo, Dunga, Marengo, Osieko and Usoma in the Lake Victoria Basin of Kenya was investigated. Colour, chloride, TSS, TDS, zinc, mercury and nitrates were all below the maximum permissible but other parameters were above limits. Pathogenic bacteria isolated were Escherichea coli (69.6\%), Salmonella spp (18.5\%), Shigella spp (6.5\%) and Vibrio cholerae (5.4\%). Dunga site was the most polluted and that water from catchment areas closer to urban areas was more contaminated. Seasonal variation showed that $\mathrm{pH}, \mathrm{colour}$, turbidity, TSS, BOD, phosphate, nitrates and coliforms were significantly high $(p<0.001)$ in the wet season. In the dry season temperature, EC, TDS, heavy metals, chloride and ammonia were significantly high $(p<0.001)$. The high level of pollutants in wet season was due to storm water run offs carrying a higher load of contaminants while in dry season it is likely due to the increased solubility of ions as a consequence of the elevated water temperature and low $\mathrm{pH}$. High loads of contaminants in water could pose immediate and long term public health concerns to unsuspecting water users especially due to the pathogenic coliforms, nutrients, algae and heavy metals. Therefore, proper policies regarding protection of the Lake Victoria environmental integrity are required and stiff measures should be taken to discourage law breakers.
\end{abstract}

Keywords: Lake Victoria; Physicochemical; Microbial; Water quality; Nutrients; Pollution

\section{Introduction}

After Lake Superior in North America, Lake Victoria is the world's second largest freshwater lake by surface area and Africa's largest with seventeen tributaries [1]. It has a surface area of $68,800 \mathrm{~km}^{2}$ with a total catchment area of $180,950 \mathrm{~km}^{2}$ and a $4,828 \mathrm{~km}$ shoreline [2]. The lake is mainly shared by three countries namely: Kenya $\left(6 \%\right.$ or $\left.4,100 \mathrm{~km}^{2}\right)$; Uganda $\left(45 \%\right.$ or $\left.31,000 \mathrm{~km}^{2}\right)$; and Tanzania $\left(49 \%\right.$ or $\left.33,700 \mathrm{~km}^{2}\right)$, but there are some sub-catchment that enter the lake waters from Burundi and Rwanda. The wetlands are a potential source of livelihood for the surrounding communities in the lake region providing a wealth of ecological, social and economic functions [3-5]. It is estimated that Lake Victoria supports over 30 million people within the three countries [6]. The rapidly growing urban populations along Lake Victoria, coupled with increasing demand for fresh water resources, and the extensive growth of agricultural and industrial activities have given rise to environmental problems [7]. High nutrient inputs have increased eutrophication levels [8-10] and also that algae biomass has increased causing the lake bottom waters to be more anoxic $[11,12]$. Heavy metal pollutants are threatening the wetland environment of Lake Victoria are trace elements [13-15]. These pollutants especially lead have been associated to increased shipping traffic, car washing and discharge from local industries [16,17]. Lake Victoria basin has also been shown to bear a great burden of diarrhoeal infections $[18,19]$. Water and some fish species commonly used as food has been shown to be contaminated with enterobacteriacea species of bacteria including Escherichia coli, Salmonella enterica serovar typhimurium and Vibrio cholerae $01[20,21]$. According to the Global International Waters Assessment Reports, four immediate causes of microbiological pollution of Lake Victoria waters are: untreated municipal sewage; runoff and storm water; animal waste and maritime transport waste [22]. However, the two most immediate causes of microbial pollution in the lake are the direct discharge of untreated municipal sewage into the lake as well as tributary rivers, runoff, and storm water. These factors have contributed to the degradation of tributary rivers as well as the lake-water quality for aquatic habitation and drinking use [7]. Several studies have documented the levels of pollution in the Lake
[9,10,16,23-25]. Review of the literature shows some gaps in these studies. Firstly, the focus has been on urban catchment areas and so information on rural areas is missing. Additionally, information on the effects of seasonal variation is limited. Also that individual studies are not comprehensive but are focused on either the physical, chemical or microbial properties but not all. Lastly, the data is about five years old or more, so the current status of pollution in the lake is necessary, especially due to the reports of high population growth and increased development activities in the lake region. This study was therefore conceived with the aim of determining the effects of seasonal variation on the physical, chemical and microbial quality of water from five rural catchment areas of Lake Victoria.

\section{Materials and Methods}

\section{Study design}

This is a cross sectional study that was conducted on the shoreline beaches of Lake Victoria at five designated rural areas. Two seasonal samplings were carried out between January and April 2013, a period that represented alternating seasons of dry (January to February) and wet seasons of the year (March to April) within the region [26].

\section{Study area}

Water samples were collected from five main fish landing beaches characterized by high populations with myriad activities taking place. These rural sites were strategically selected considering that they were

*Corresponding author: Ouma SO, Department of Biochemistry and Biotechnology, Kenyatta University, PO Box 43844-00100, Nairobi, Kenya, Tel: +2540728993404; E-mail: seth_ouma@yahoo.com

Received December 21, 2015; Accepted December 29, 2015; Published January 09, 2016

Citation: Ouma SO, Ngeranwa JN, Juma KK, Mburu DN (2016) Seasonal Variation of the Physicochemical and Bacteriological Quality of Water from Five Rural Catchment Areas of Lake Victoria Basin in Kenya. J Environ Anal Chem 3: 170. doi:10.41722380-2391.1000170

Copyright: ( 2016 Ouma SO, et al. This is an open-access article distributed under the terms of the Creative Commons Attribution License, which permits unrestricted use, distribution, and reproduction in any medium, provided the original author and source are credited. 
subject to either industrial waste discharge, municipal, sewage, toxic waste disposal and wastewater irrigation activities taking place. The five sampling sites were Luanda Rombo, Dunga, Marengo, Osieko and Usoma beaches (Figure 1). Luanda Rombo beach is in Homa Bay County with an area of $7.0 \mathrm{~km}^{2}$ and a population density of 317 . Dunga is a peri-urban region located in Kisumu County with an area of 4.7 $\mathrm{km}^{2}$ and it had the highest population density of 6,886 [27]. Usoma beach is in Asembo Bay, Siaya County while Marengo and Osieko beaches are located in Busia County. The main activities around the study areas include; marine and road transport, car washing, crop and animal husbandry, fish processing and human settlement.

\section{Sampling}

Water samples were collected following standard sampling guidelines and methods [21,28]. Within each site, approximately 12 duplicate composite samples were taken weekly from three different locations separated at least $10-15 \mathrm{~m}$ from the shoreline. This worked out to nine samples at every beach, for a total of 45 samples. Since sampling was done for four months, twice per season, this brought the sample size to 90 per season, and for a total of 180 for both seasons.

\section{Physical analysis}

At each sampling station, temperature, $\mathrm{pH}$, electrical conductivity, dissolved oxygen and turbidity were determined in situ. The $\mathrm{pH}$ was measured using a $\mathrm{pH}$ meter; turbidity using turbidity meter while temperature/electrical conductivity using conductivity meter while dissolved oxygen was determined using DO-meter probe. Total suspended solid and TDS were determined by gravimetric method [29].

\section{Chemical analysis}

One hundred milllitres aliquot of acid pre-treated sample was filtered and analyzed using atomic absorption spectrophotometer. Ammonium concentration was determined by indophenol method involving oxidation with sodium hypochlorite and phenol solution. Nitrate was analyzed by cadmium reduction and diozoic complex followed by spectrophotometric analysis. Phosphate was analyzed by use of ascorbic acid followed by turbidimetric analysis. Biochemical Oxygen Demand was determined using by using BOD OxiTop meter [30].

\section{Bacteriological analysis}

Bacteriological analysis was performed as per standard microbiological methods [31]. These involved presumptive, confirmatory and completed tests [32]. Total and fecal coliform groups were determined by multi-tube fermentation methods [33]. Presumptive test analysis was done using Mac Conkey broth to enumerate total coliforms while confirmatory test analysis of the samples was done using brilliant green broth to enumerate fecal coliforms. Dihydroxycholate hydrogen sulphide lactose agar, Xylose lysine deoxycholate agar, Salmonella- shigella agar and Thiosulphate citrate bile salt sucrose agar were used to determine heterotrophic bacteria; E. coli, Shigella, Salmonella and Vibrio cholerae respectively. All plates were incubated at $35^{\circ} \mathrm{C}$ for $24 \mathrm{~h}$ and the colonies were identified based on morphological characteristics. Presumptive colonies were confirmed by gram staining and biochemical reactions and each plate was given a positive or negative score. Isolates were confirmed by some conventional biochemical test [34].

\section{Data analysis}

Comparison for variations between the sampling sites was done using one way ANOVA. Tukey's post hoc test for multiple comparisons was performed on the data that was statistically significant. Paired t-test was used to analyze the seasonal variations between the dry and wet

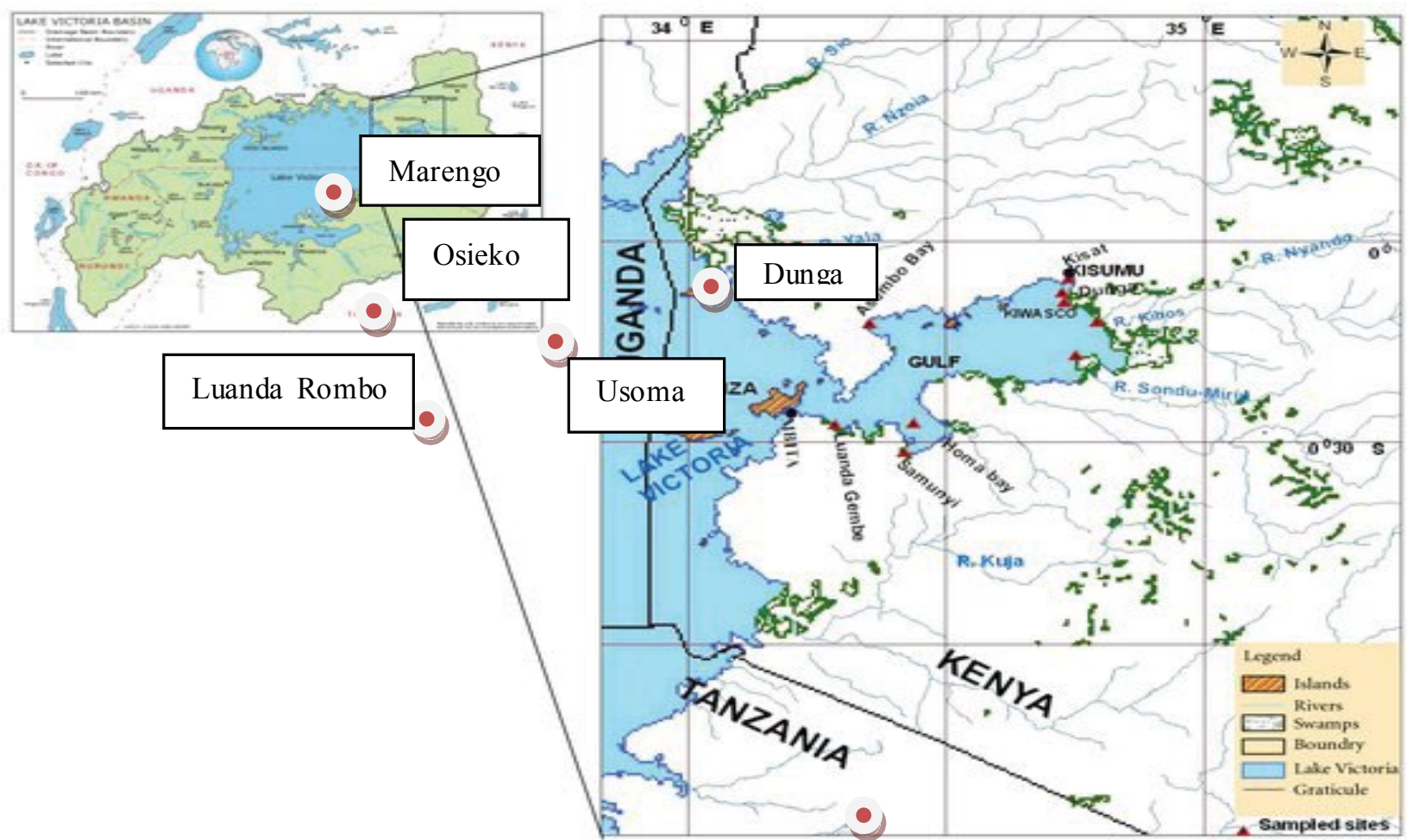

Figure 1: Map of the Nyanza Gulf, Lake Victoria showing the sampling sites. 
season. Relationships between selected physico-chemical parameters $(p<0.05)$ in the five selected catchment areas of Lake Victoria was carried out using Pearson's correlation.

\section{Results}

\section{Physicochemical properties}

Physico-chemical parameters of water sampled from the beaches of Dunga, Luanda Rombo, Usoma, Osieko and Marengo are presented in Tables 1-3. The data shows that colour, TSS, and TDS were all within the maximum permissible limit as per the WHO standards for portable water. However, Dunga had the significantly $(p<0.001)$ high levels of TSS and TDS, than at the other four sampling sites. Paired comparison using $t$ test indicated that colour and TSS were significantly high $(p<0.001)$ in the wet season, while TDS was significantly high $(p<0.001)$ in the dry season. Most $\mathrm{pH}$ values were within the permissible range except for Dunga (8.9) in the wet season. On the other hand seasonal variation shows that $\mathrm{pH}$ was significantly low $(p<0.001)$ in the dry season. Water temperature was within the limit in the wet season $\left(25-25.1^{\circ} \mathrm{C}\right)$ but was above limit in the dry season $\left(25.7-27^{\circ} \mathrm{C}\right.$; $\left.p<0.05\right)$. Electrical conductivity $(420-753 \mu \mathrm{S} / \mathrm{cm})$ and turbidity $(279-554 \mathrm{mg} / \mathrm{L})$ were all above the maximum permissible limit. Site differences show that water from Dunga had the highest EC and turbidity values and that these values were significantly different $(p<0.001)$ from those at the other sites. Paired comparison using $t$ test showed that EC was significantly high $(p<0.001)$ in the dry season while turbidity was significantly high $(p<0.001)$ in the wet season. Most of the DO values were below the minimum permissible limit $(>5)$ except for Luanda Rombo $(5.3 \mathrm{mg} / \mathrm{L})$ and Usoma $(5.5 \mathrm{mg} / \mathrm{L})$ which were within the permissible limit in the wet season. Tukey's post hoc test for multiple comparisons showed that the DO levels in Dunga were significantly low $(p<0.001)$ than those in Usoma and Luanda Rombo. The DO levels were also low in Osieko compared to Usoma $(p<0.05)$. Seasonal variation indicated that DO levels were significantly high $(p<0.001)$ in the wet season, while BOD values (170-330 mg/L) were above limits. Analysis of variance showed that there was no significant difference $(p=0.208)$ in the BOD values between the different sites. Paired comparison using $t$ test showed that BOD values were significantly high $(p<0.001)$ in the dry season. Pearson's correlation coefficient analysis was done to determine the level of association between selected physical parameters. The $r$ values for these pairs ranged from a low of $0.03(p=0.961)$ between EC/turbidity in dry season to a high of $0.8473(p=0.0699)$ between turbidity/TSS in the wet season. Significant positive association was observed between the following pairs: BOD/TDS ( $r=0.7531, p=0.0199)$, $\mathrm{BOD} / \mathrm{EC}(r=0.7101, p=0.0214)$ and $\mathrm{BOD} /$ Temperature $(r=0.9199$, $p=0.0002)$. While there was a significant negative correlation between $\mathrm{BOD} / \mathrm{DO}(r=-0.859 ; p=0.0015)$.

\section{Chloride and nutrients}

Table 2 shows the level of chloride and nutrients at the five sampling sites. The chloride levels ranged from $41 \mathrm{mg} / \mathrm{L}$ in Dunga during the wet season to $82 \mathrm{mg} / \mathrm{L}$ at the same site in the dry season. Nitrates $(0.15-2.23$ $\mathrm{mg} / \mathrm{L})$ and phosphate $(0.18-1.22 \mathrm{mg} / \mathrm{L}$ ) levels were with permissible limits. For ammonia most values were within limits except in Luanda Rombo where they were elevated $(0.7 \mathrm{mg} / \mathrm{L})$ in the wet season. In the dry season it was the reverse in that ammonia levels $(0.54-0.73 \mathrm{mg} / \mathrm{L})$ were above the permissible limit except for Luanda Rombo $(0.43 \mathrm{mg} / \mathrm{L})$ where values were within limit. There were significant differences in nitrates levels between the following sites: Dunga $v s$ Usoma $(P<0.05)$ and Dunga vs Marengo $(P<0.05)$. On the other hand seasonal variations showed that the nitrates and phosphate levels were significantly high $(p<0.001)$ in the wet season while ammonia was significantly high $(p<0.001)$ in the dry season.

\section{Heavy metals}

Zinc and mercury were all within the maximum permissible limit, except, at Luanda Rombo where trace levels of the latter were reported (Table 3). Iron levels were also within the permissible limit apart for one sample from Dunga $(0.318 \mathrm{mg} / \mathrm{L})$ in the dry season. For aluminium, all values in the dry season $(0.32-0.7616 \mathrm{mg} / \mathrm{L})$ were above limit, just like in Usoma $(0.34 \mathrm{mg} / \mathrm{L})$ and Dunga $(0.46 \mathrm{mg} / \mathrm{L})$ in wet season. Dunga had significantly high $(p<0.001)$ levels of lead and iron than the other four sites. Seasonal variations showed that the levels of heavy metals were significantly high $(p<0.001)$ in the dry except for lead $(p=0.973)$ there were no seasonal differences. Pearson's correlation coefficient between all the metal showed only one significant positive correlation between lead and mercury $(r=0.981 ; p<0.05)$.

\section{Bacteriological analysis}

Figures 2 and 3 show the distribution of total coliforms and fecal coliforms in water sampled from the five sites. Out of the 180 samples, $163(90.6 \%)$ tested positive for total coliforms and had MPN values above WHO recommended limit of $10 \mathrm{CFU} / 100 \mathrm{ml}$. Seasonal variation shows that the total coliforms were significantly high $(p<0.001)$ in the wet season (84) when compared to the dry season (79). For fecal coliforms, out of the 163 samples that tested positive for total coliforms, $98(60.1 \%)$ were positive for fecal coliforms. When compared by site the only significant difference in number of fecal coliforms between sites was that between Dunga and Marengo $(p<0.001)$. Seasonal variation shows that fecal coliforms were significantly high $(\mathrm{p}<0.001)$ in the wet season (52) when compared to the dry season (48). Out of the 98 samples positive for fecal coliform candidates, 92 tested positive for the four viable enterobacterial genera on respective selective culture media, while for six no viable bacterial cultures were isolated because of their non-selectivity on the culture media used. Biochemical tests further revealed that the pure cultures of the six samples that however developed viable colonies on MacConkey general agar media were

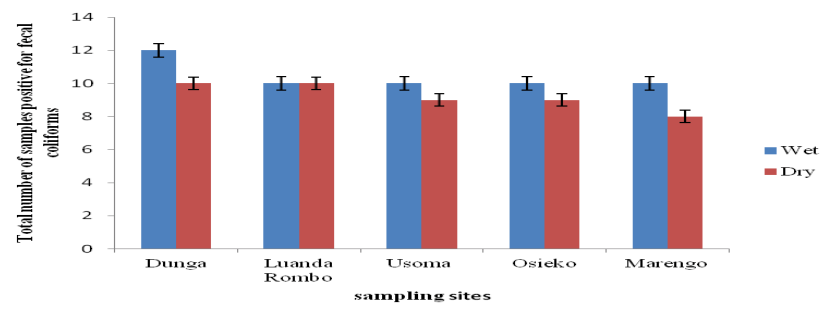

Figure 2: Seasonal prevalence of total coliforms from the five study sites in Lake Victoria basin in Kenya.

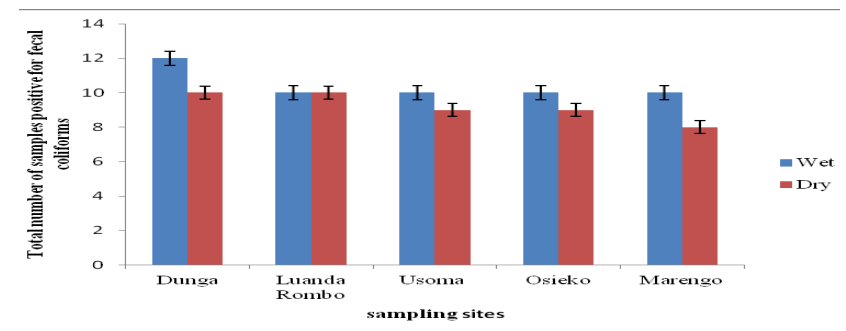

Figure 3: Seasonal prevalence of fecal coliforms from the study sites in Lake Victoria basin in Kenya. 
Citation: Ouma SO, Ngeranwa JN, Juma KK, Mburu DN (2016) Seasonal Variation of the Physicochemical and Bacteriological Quality of Water from Five Rural Catchment Areas of Lake Victoria Basin in Kenya. J Environ Anal Chem 3: 170. doi:10.41722380-2391.1000170

Page 4 of 7

\begin{tabular}{|c|c|c|c|c|c|c|c|c|c|c|c|}
\hline \multirow[t]{2}{*}{ Parameter } & \multicolumn{2}{|c|}{ Dunga } & \multicolumn{2}{|c|}{ Luanda Rombo } & \multicolumn{2}{|c|}{ Usoma } & \multicolumn{2}{|c|}{ Osieko } & \multicolumn{2}{|c|}{ Marengo } & \multirow{2}{*}{$\begin{array}{c}\text { WHO } \\
\text { standards }\end{array}$} \\
\hline & Wet & Dry & Wet & Dry & Wet & Dry & Wet & Dry & Wet & Dry & \\
\hline $\mathrm{pH}$ & $8.9 \pm 0.067^{\circ}$ & $8.1 \pm 0.0527$ & $7.9 \pm 0.058^{\mathrm{a}}$ & $7.2 \pm 0.025^{c}$ & $7.8 \pm 0.039^{a}$ & $7.6 \pm 0.042$ & $7.4 \pm 0.039^{b}$ & $7.8 \pm 0.0866^{a}$ & $7.7 \pm 0.024$ & $6.8 \pm 0.111^{b}$ & $6.5-8.5$ \\
\hline Colour (HU) & $12.7 \pm 0.193^{a}$ & $9.1 \pm 0.2582^{b}$ & $11 \pm 0.236^{b}$ & $7.0 \pm 0.4392^{\mathrm{a}}$ & $12 \pm 0.236^{\mathrm{a}}$ & $8.9 \pm 0.1389^{b}$ & $12 \pm 0.243^{\mathrm{a}}$ & $6.7 \pm 0.27^{\mathrm{a}}$ & $14 \pm 0.243^{c}$ & $8.5 \pm 0.27^{a}$ & 15 \\
\hline Temp $\left({ }^{\circ} \mathrm{C}\right)$ & $25.1 \pm 0.242^{\mathrm{a}}$ & $27 \pm 0.222^{\mathrm{a}}$ & $25.1 \pm 0.229^{a}$ & $26 \pm 0.362^{\mathrm{a}}$ & $25.1 \pm 0.266^{\mathrm{a}}$ & $25.9 \pm 0.237^{a}$ & $25.7 \pm 0.506^{\mathrm{a}}$ & $25 \pm 0.385^{\mathrm{a}}$ & $25 \pm 0.242^{\mathrm{a}}$ & $26.1 \pm 0.273^{\mathrm{a}}$ & 25 \\
\hline $\mathrm{EC}(\mu \mathrm{S} / \mathrm{cm})$ & $587 \pm 3.662^{c}$ & $753 \pm 8.049^{d}$ & $489 \pm 6.196^{\mathrm{a}}$ & $568 \pm 2.8033^{a}$ & $501 \pm 6.930^{\mathrm{a}}$ & $529 \pm 3.8374^{c}$ & $433 \pm 4.581^{b}$ & $587 \pm 5.5581^{\mathrm{a}}$ & $420 \pm 3.706^{b}$ & $476 \pm 27711^{\mathrm{b}}$ & $<400$ \\
\hline Turb (NTU) & $554 \pm 6.975^{c}$ & $369 \pm 2.033^{\circ}$ & $320 \pm 2.187^{b}$ & $290 \pm 5.826^{\mathrm{ab}}$ & $408 \pm 3.766^{a}$ & $300 \pm 2.481^{a}$ & $411 \pm 2.794^{a}$ & $389 \pm 3.473^{d}$ & $404 \pm 2.068^{a}$ & $279 \pm 6.454^{b}$ & $<5$ \\
\hline TSS (mg/L) & $397 \pm 4.284^{d}$ & $298 \pm 5.507^{d}$ & $199 \pm 2.804^{\mathrm{a}}$ & $124 \pm 4.1787^{b}$ & $344 \pm 6.652^{c}$ & $216 \pm 1.3054^{c}$ & $289 \pm 5.111^{b}$ & $190 \pm 1.8309^{a}$ & $216 \pm 3.116^{a}$ & $191 \pm 2.1383^{a}$ & $<500$ \\
\hline TDS (mg/L) & $382 \pm 5.269^{\circ}$ & $407 \pm 1.171^{c}$ & $212 \pm 9.901^{\mathrm{a}}$ & $264 \pm 2.5086^{b}$ & $212 \pm 9.804^{\mathrm{a}}$ & $259 \pm 3.4152^{\mathrm{b}}$ & $208 \pm 5.747^{a}$ & $328 \pm 1.781^{\mathrm{a}}$ & $249 \pm 13.800^{b}$ & $331 \pm 2.641^{a}$ & $<500$ \\
\hline $\mathrm{DO}(\mathrm{mg} / \mathrm{L})$ & $4.2 \pm 0.054^{a}$ & $3.1 \pm 0.052^{c}$ & $5.3 \pm 0.059^{d}$ & $4.2 \pm 0.076$ & $5.5 \pm 0.0400^{e}$ & $4.3 \pm 0.045^{a}$ & $4.4 \pm 0.023^{b}$ & $3.9 \pm 0.0404^{b}$ & $4.7 \pm 0.023^{c}$ & $3.7 \pm 0.062^{b}$ & 5 \\
\hline $\mathrm{BOD}(\mathrm{mg} / \mathrm{L})$ & $240 \pm 2.302^{d}$ & $330 \pm 6.181^{b}$ & $170 \pm 1.667^{\mathrm{a}}$ & $290 \pm 9.895^{a}$ & $180 \pm 1.451^{b}$ & $280 \pm 3.228^{a}$ & $170 \pm 1.077^{a}$ & $290 \pm 2.887^{\mathrm{a}}$ & $190 \pm 1.348^{c}$ & $300 \pm 3.481^{\mathrm{a}}$ & 150 \\
\hline
\end{tabular}

Temp=temperature; EC=electrical conductivity; Turb=turbidity; TSS=total suspended solids; TDS=total dissolved solids; $\mathrm{DO}=\mathrm{dissolved}$ oxygen ,BOD=biological oxygen demand

Table 1: Physicochemical characteristics of water during the wet and dry season at the selected five rural catchment areas of Lake Victoria.

\begin{tabular}{|c|c|c|c|c|c|c|c|c|c|c|c|}
\hline \multirow[t]{2}{*}{ Parameter } & \multicolumn{2}{|c|}{ Dunga } & \multicolumn{2}{|c|}{ Luanda Rombo } & \multicolumn{2}{|c|}{ Usoma } & \multicolumn{2}{|c|}{ Osieko } & \multicolumn{2}{|c|}{ Marengo } & \multirow{2}{*}{$\begin{array}{c}\text { WHO } \\
\text { standards } \\
\text { (mg/L) }\end{array}$} \\
\hline & Wet & Dry & Wet & Dry & Wet & Dry & Wet & Dry & Wet & Dry & \\
\hline Chloride & $41 \pm 3.77^{\circ}$ & $82 \pm 24.04^{a}$ & $38 \pm 11.79^{b}$ & $57 \pm 1.65^{b}$ & $47 \pm 2.47^{a}$ & $79 \pm 1.77^{a}$ & $47 \pm 3.77^{\mathrm{a}}$ & $75 \pm 5.19^{c}$ & $47 \pm 2.71^{\mathrm{a}}$ & $80 \pm 2.59^{a}$ & $<250$ \\
\hline Nitrates & $2.23 \pm 0.029^{e}$ & $1.04 \pm 0.0193^{a}$ & $1.58 \pm 0.0063^{c}$ & $0.99 \pm 0.0148^{a}$ & $1.17 \pm 0.0043^{b}$ & $0.15 \pm 0.0046^{c}$ & $2.02 \pm 0.014^{d}$ & $0.79 \pm 0.0197^{d}$ & $2.09 \pm 0.0037^{a}$ & $1.02 \pm 0.0141^{a}$ & 45 \\
\hline Phosphate & $1.22 \pm 0.0052^{e}$ & $0.21 \pm 0.0047^{b}$ & $0.86 \pm 0.0054^{c}$ & $0.29 \pm 0.0061^{a}$ & $0.96 \pm 0.0041^{\mathrm{d}}$ & $0.18 \pm 0.0035^{c}$ & $0.79 \pm 0.0103^{b}$ & $0.23 \pm 0.006^{b}$ & $0.96 \pm 0.0169^{a}$ & $0.28 \pm 0.0048^{a}$ & 0.1 \\
\hline Ammonia & $0.33 \pm 0.0048^{c}$ & $0.72 \pm 0.006^{e}$ & $0.700 \pm 0.0041^{a}$ & $0.43 \pm 0.0036^{a}$ & $0.19 \pm 0.0031^{a}$ & $0.54 \pm 0.0082^{b}$ & $0.22 \pm 0.0052^{b}$ & $0.63 \pm 0.004^{d}$ & $0.19 \pm 0.0071^{a}$ & $0.59 \pm 0.004^{c}$ & 0.5 \\
\hline
\end{tabular}

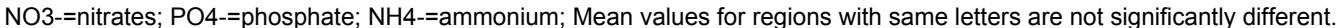

Table 2: Chloride and nutrients concentrations in water sampled during wet and dry seasons at the selected five study regions within Lake Victoria.

\begin{tabular}{|c|c|c|c|c|c|c|c|c|c|c|c|}
\hline \multirow[t]{2}{*}{ Parameter } & \multirow{2}{*}{$\begin{array}{c}\text { Dunga } \\
\text { Wet }\end{array}$} & \multirow[b]{2}{*}{ Dry } & \multicolumn{2}{|c|}{ Luanda Rombo } & \multicolumn{2}{|c|}{ Usoma } & \multicolumn{2}{|c|}{ Osieko } & \multicolumn{2}{|c|}{ Marengo } & \multirow{2}{*}{$\begin{array}{c}\text { WHO } \\
\text { standards } \\
\text { (mg/L) }\end{array}$} \\
\hline & & & Wet & Dry & Wet & Dry & Wet & Dry & Wet & Dry & \\
\hline Zinc & $0.029 \pm 0.0006^{a}$ & $0.071 \pm 0.0008^{a}$ & $0.016 \pm 0.0004^{c}$ & $0.037 \pm 0.0006^{a}$ & $0.025 \pm 0.0004^{d}$ & $0.057 \pm 0.0007^{\mathrm{a}}$ & $0.013 \pm 0.0004^{b}$ & $0.038 \pm 0.0006^{a}$ & $0.027 \pm 0.0006^{a}$ & $0.061 \pm 0.0192^{a}$ & $<5.0$ \\
\hline $\mathrm{Al}$ & $0.460 \pm 0.0043^{\mathrm{d}}$ & $0.616 \pm 0.0068^{\mathrm{d}}$ & $0.250 \pm 0.0068^{a}$ & $0.430 \pm 0.0046^{a}$ & $0.340 \pm 0.0111^{\circ}$ & $0.580 \pm 0.0053^{c}$ & $0.240 \pm 0.0024^{\mathrm{a}}$ & $0.430 \pm 0.0046^{a}$ & $0.27 \pm 0.0021^{b}$ & $0.32 \pm 0.0246^{b}$ & $<0.3$ \\
\hline Iron & $0.273 \pm 0.0007^{a}$ & $0.318 \pm 0.0399^{a}$ & $0.167 \pm 0.0005^{a}$ & $0.291 \pm 0.004^{a}$ & $0.074 \pm 0.0003^{b}$ & $0.093 \pm 0.0005^{a}$ & $0.117 \pm 0.0129^{a}$ & $0.145 \pm 0.0006^{a}$ & $0.122 \pm 0.0385^{a}$ & $0.176 \pm 0.0005^{a}$ & $<0.3$ \\
\hline $\mathrm{Hg}$ & ND & ND & ND & ND & ND & ND & ND & ND & ND & ND & 0 \\
\hline $\mathrm{Pb}$ & $0.308 \pm 0.0004^{a}$ & $0.895 \pm 0.0031^{\circ}$ & $0.080 \pm 0.0008^{b}$ & $0.162 \pm 0.0005^{b}$ & $0.089 \pm 0.0034^{c}$ & $0.294 \pm 0.0025^{a}$ & $0.148 \pm 0.0008^{e}$ & $0.287 \pm 0.0004^{\mathrm{a}}$ & $0.124 \pm 0.0004^{d}$ & $0.292 \pm 0.0005^{a}$ & $<0.05$ \\
\hline
\end{tabular}

Mean values for regions with same letters are not significantly different; ND=not detected

Table 3: Concentrations of heavy metals in water sampled at five rural catchment areas within Lake Victoria.

non-lactose fermenters on TSI biochemical thus revealing that they neither belonged to any of the 4 main bacterial genera isolated nor enterobacteria family. The distribution of the enterobacterial genera in Dunga, Luanda Rombo, Usoma, Osieko and Marengo sampling sites was that from the 92 fecal coliform positive samples 64 (69.6\%) were Escherichia coli, 17 (18.5\%) Salmonella spp, 6 (6.5\%) Shigella, spp and 5 (5.4\%) Vibrio cholerae (Figure 4). From this study, Escherichia coli was the most predominant enterobacterial isolate during both wet and dry seasons and across all the study sites. Vibrio cholerae was the least isolated enterobacteria with none being isolated at Osieko beach in both seasons, and in Luanda Rombo and Usoma in wet season, while in Dunga it was in the dry season. Analysis of variance indicated that there were no significant differences in the number of Escherichia coli $(p=0.986)$, Salmonella $\operatorname{sp} p(p=0.774)$ and Vibrio cholerae $(p=0.995)$ between the five sampling sites. However, Dunga had significantly high $(P<0.001)$ number of Shigella $s p p$ than the other four sites. Seasonal variations showed that there was no significant difference in the number of Escherichia coli $(p=0.126)$, Salmonella $\operatorname{spp}(p=0.633)$ and Vibrio cholerae $(p=0.176)$ between the wet and dry season, however, there were significantly high $(p<0.05)$ numbers of Shigella $s p p$ in the dry season.

\section{Discussion}

Colour, TSS and TDS were all within permissible limit for portable water [35]. Likewise water temperature was within the limits except in the the dry season. Elevation of water temperature is contributed by factors including sunlight/solar radiation, heat transfer from the atmosphere, stream confluence and turbidity [36,37]. Here the high temperature was confined to the dry season. The $\mathrm{pH}$ of water was within the permissible limits except at Dunga (8.9) in the wet season. The high alkaline $\mathrm{pH}$ in Dunga can be due to industrial pollutant or other factors. This $\mathrm{pH}$ is undesirable for it has the potential of indirectly affecting the biota in various ways for instance it can cause irritation and inflammation of the mucous membranes of humans and animals using the water [38]. Thus, making them more vulnerable to opportunistic infections; it can also cause toxicity to fish through accumulation of the unionized ammonia on the gill surface [39]. Seasonal variations showed that $\mathrm{pH}$ was low in the dry season. Low $\mathrm{pH}$ is known to favour the solubility of ions associated with TDS [40]. So it can be deduced that the significantly high levels of TDS observed in this study was likely due to the low $\mathrm{pH}$ of water. We observed that most $\mathrm{DO}$ values (3.1-4.7 $\mathrm{mg} / \mathrm{L}$ ) were below the permissible limits and this compares well with the findings of Lung'ayia et al. [9] and Muyodi et al. [10] who reported DO levels of between $0.9 \mathrm{mg} / \mathrm{L}$ and $4.9 \mathrm{mg} / \mathrm{L}$ in selected catchment areas of the Lake Victoria basin in Kenya and Tanzania. Reduced DO levels in water has been attributed to the favorable temperatures and increased nutrient levels, hence increased photosynthetic activities of algae [41]. This association is supported by our observations in that, in addition to the water having reduced DO levels there was elevation of temperature and a high load of phosphate and ammonia. The biological oxygen demand levels were above the permissible limits at all sites and this exposes fish and other aquatic organisms to less oxygen and this is likely to affect their growth, development and performance. The low DO and high BOD is a further testament of the increased levels of pollution in the waters of LV. It is alleged that pollution affecting the two parameters is more likely attributed to human sewerage, 


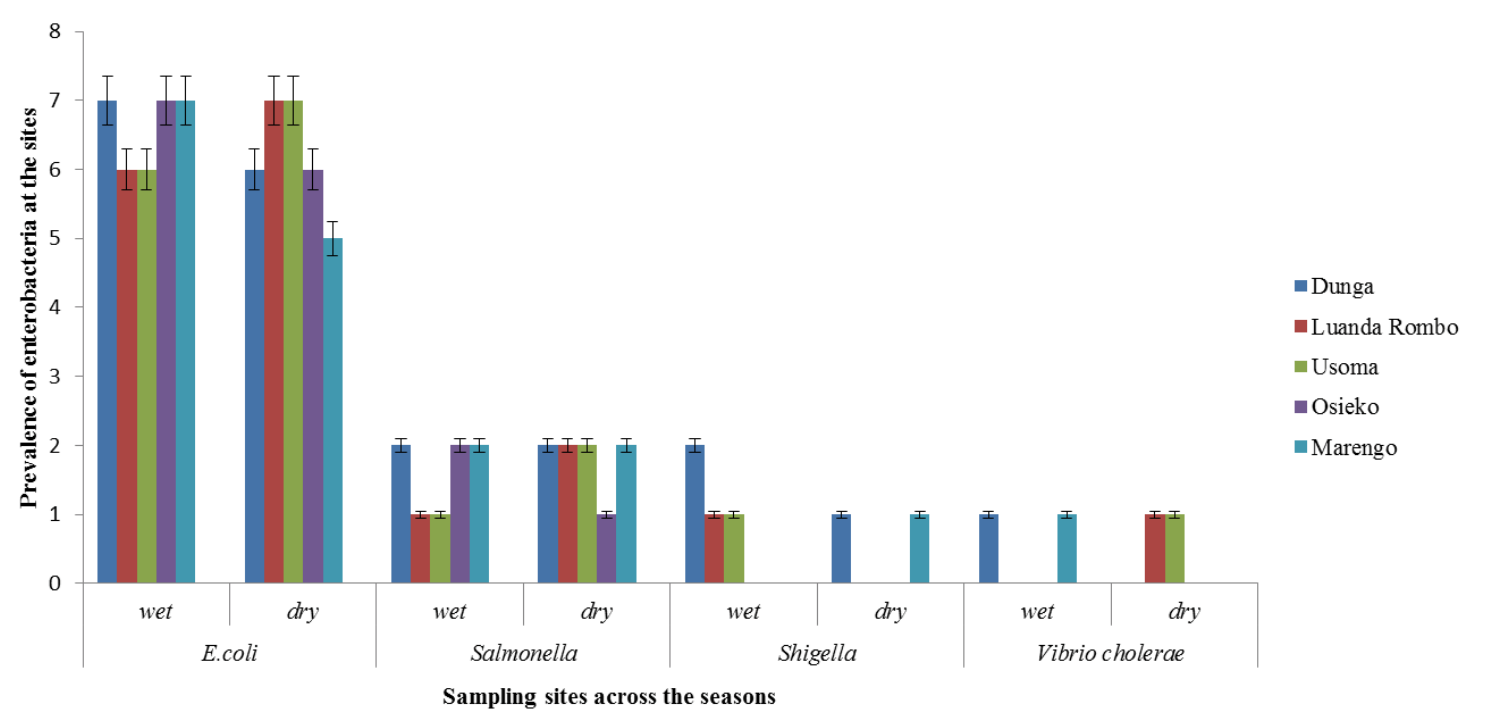

Figure 4: Regional and seasonal distribution of four bacterial genera isolated in five selected study areas of rural Lake Victoria basin.

breweries waste, nutrients eutrophication and decomposition of organic wastes, effluents from sugar-cane factories, fish processing and soap industries [42]. It is noted that most of these pollutants are prevalent at the study areas, especially at Dunga. Electrical conductivity values were all above the permissible limits and the levels were high in the dry season $(476-753 \mu / \mathrm{cm})$ when compared to the wet season. High EC values are mostly associated with wastewater discharges from sewerage, agricultural runoff and industries [43], all of which are a factor at the study areas. Turbidity levels also crossed the maximum permissible limits. Clay, silt, finely divided inorganic and organic matter, algae, soluble colored organic compounds, and plankton and other microscopic organisms are associated with turbidity [44-46]. In this study the high levels of turbidity are more likely to be associated with the high load of coliforms that was way above the allowed limits $[34,47]$. Nutrients, especially ammonia, phosphates and nitrates are known to favour microorganism bloom. Elevated ammonium levels predominantly during dry season in almost all study sites is attributed to discharges of untreated human sewage into the lake from areas surrounding urban as well as informal settlements [48]. Here we report high levels of phosphate (0.18-1.22 mg/L) and ammonia (0.19-0.72) in waters of Lake Victoria. Comparison of previous studies with the present work shows a consistent rise in the level of nutrients level in Lake Victoria. Njuru [23] had reported phosphate levels of 0.007$0.057 \mathrm{mg} / \mathrm{L}$ and nitrates of between $0.005-0.037 \mathrm{mg} / \mathrm{L}$ at nine sampling stations within Lake Victoria. In a previous study nitrate levels of between $0.0076 \mathrm{mg} / \mathrm{L}-0.0559 \mathrm{mg} / \mathrm{L}$ while the ammonium load was $0.0989 \mathrm{mg} / \mathrm{L}-0.5987 \mathrm{mg} / \mathrm{L}$ at three catchment areas on the Kenyan side of Lake Victoria were reported [10]. The data presented here show that there is continued degradation of the physical properties of water from Lake Victoria when compared to past studies [9,10,23-25,47]. In one of the study [49] the levels of $\mathrm{pH}$, temperature, EC, TSS and TDS were 6.69.0, $24-27^{\circ} \mathrm{C}, 91-369 \mu / \mathrm{cm}, 0-33 \mathrm{mg} / \mathrm{L}$ and $41-170, \mathrm{mg} / \mathrm{L}$ respectively; while in our present study the values were $6.8-8.9,25-27^{\circ} \mathrm{C}, 420-753$ $\mu / \mathrm{cm}, 124-397 \mathrm{mg} / \mathrm{L}$ and $208-407 \mathrm{mg} / \mathrm{L}$, respectively. The low levels of zinc, mercury and iron at most of the sites could be attributed to low source factors [10]. The high levels of aluminium may be associated with the rapid industrial activities such as steel rolling mills in the area. Lead levels were also elevated throughout the study area. The major source of lead pollution is paint, car batteries, petrol as well as industrial discharges [24], all of which are prevalent in the Lake basin region. All the study sites recorded high number of coliforms which were significantly high in the wet season. The high total coliform loads recorded is mostly attributed to organic deposits predominantly from human and animal sewerage as well as high suspended solid matter [50]. Activities at the shoreline including washing clothes and cars and bathing are other potential sources of fecal contamination. The high load of contaminants in the the wet season is a consequence of the high volume surface runoff deposits from sewage contaminated with human and animal wastes from land based sources. The predominant isolate was Escherichia coli (69.6\%) followed by Salmonella (18.5\%), Shigella (6.5\%) while Vibrio cholerae was the least isolate (5.4\%). These results agree with previous studies that showed that Lake Victoria bears a great burden of pathogens associated with diarrhoeal infections $[18,19]$. In another study S. Typhimurium (49.6\%) was the predominant isolate followed by E. coli and V. cholerae with prevalences of $46.6 \%$ and $3.8 \%$, respectively [21]. It is therefore concluded that the waters were contaminated with bacteria at levels that are above the WHO standards for portability. As is with other parameters Dunga recorded slightly a high number of the pathogenic enterobacterial isolates. The high levels of pollution in Dunga are attributed to the following factors: First, the site has the largest number of activities known to generate a high load of pollutants. It also has a high human population [27], meaning that human activities and interventions are likely to contribute to higher pollution. In addition, Dunga is in close proximity to Kisumu city, thus, predisposing it to high loads of toxic discharges from the effluents from various industries including breweries, tannery, fish processing, agro processing plants and abattoirs.

\section{Conclusion}

This study shows that majority of the physicochemical and microbial parameters crossed the permissible limits of portable water and pollutants levels are higher than in earlier studies, thus, suggesting a continuation with contamination, and this is a worrying trend. The water is more polluted in catchment areas that are closer to urban areas than those further away. Seasonal variations indicate that $\mathrm{pH}$, colour, turbidity, TSS, BOD, phosphate, nitrates and coliforms were significantly high in the wet season while in the dry season temperature, EC, TDS, heavy metals, chloride and ammonia were significantly high. 
The high levels of pollutants in the wet season is more associated with storm water run offs carrying a higher load of contaminants and in the dry season it is more likely due to the increased solubility of ions as a consequence of the elevated water temperature and low $\mathrm{pH}$. Dunga is the most polluted site. The contaminated water could pose immediate and long term public health concerns to unsuspecting water users especially due to the high levels of the pathogenic coliforms, nutrients, algae and heavy metals. Immediate health concerns include typhoid, dysentery and cholera. Therefore, proper policies regarding protection of the Lake Victoria environmental integrity are required and stiff measures should be taken to discourage law breakers.

\section{Acknowledgements}

We are particularly grateful to Kenya Water Institute for their cooperation, technical and facility support during the research. We thank Joyce Mwini Kinoti of Nairobi City Water and Sewerage Company for technical support during the study. We are also thankful to Professor Yashon Ouma and Dr. Leunitta Sumba for their valuable support throughout the study period.

\section{References}

1. Nicholson SE (1998) Historical fluctuations of Lake Victoria and other lakes in the northern Rift Valley of East Africa. In Environmental change and response in East African lakes, Springer, The Netherlands. pp: 7-35.

2. Machiwa PK (2008) Water quality management and sustainability: The experience of Lake Victoria Environmental Management Project (LVEMP)Tanzania.

3. Mafabi SV, Swai D, Mugabe R (1998) A review of heavy metal removal mechanisms in Wetlands. African Journal of Tropical Hydrobiology and Fisheries 8: 23-35.

4. Namakambo N (2000) Kampala wetlands. National Wetlands Program.

5. Swallow BM, Walsh M, Mugo F, Ong C, Shepherd K, et al. (2002) Improved and management of the Lake Victoria basin: Annual Technical Report.

6. Okedi JO (2005) A historical perspective of the challenges and opportunities in management of the Lake Victoria fisheries: lessons for the future: In proceeding of the regional stakeholders' conference, 24th-25th February 2005; The State of the Fisheries Resources of Lake Victoria and their Management. Entebbe - Uganda.

7. Ntiba MJ, Kudoja WM, Mukasa CT (2001) Management issues in the Lake Victoria.watershed. Lakes Reservoirs: Resource Management 6: 211-216.

8. Hecky RE, Mugidde R, Bugenyi FWB, Wang X (2000) Phosphorus in Lake Victoria waters and sediments: Sources, loadings, sinks and anthropogenic mobilization. In Proceedings of the International Conference on Lake Victoria, Jinja, Uganda.

9. Lung'ayia H, Sioki L, Kenyanya LS (2001) The nutrient enrichment of Lake Victoria (Kenyan waters). Hydrobiologia 458: 75-82.

10. Muyodi FJ, Hecky RE, Kitamirike JM, Odong R (2009) Trends in health risks from water-related diseases and cyanotoxins in Ugandan portion of Lake Victoria basin. Lakes Reservation. Research Management 14: 247-257.

11. Guildford SJ, Hecky RE (2000) Total nitrogen, total phosphorus, and nutrient limitation in lakes and oceans: Is there a common relationship? Limnology and Oceanography 45: 1213-1223.

12. Mugidde R (2003) Pelagic nitrogen fixation in Lake Victoria, Uganda. Journal of Great Lakes Research 29: 76-88.

13. Nabulo G, Oryem-Origa H, Nasinyama GW, Cole D (2008) Assessment of Zn, $\mathrm{Cu}, \mathrm{Pb}$ and $\mathrm{Ni}$ contamination in wetland soils and plants in the Lake Victoria basin. International Journal of Environmental Science and Technology 5: 65-74

14. Henry L, Omutange E (2009) Fractionation of trace metals between catchment soils and associated wetland sediments of selected wetlands of Lake Victoria, East Africa. Journal of Wetlands Ecology 3: 68-76.

15. Mutakyahwa MKD, Ikingura JR, Mtui GYS (2009) Monitoring of heavy metal loading into the wetlands south of Lake Victoria basin, Northern Tanzania. Tanzania. Journal of Science 35: 17-36.

16. Wandiga S, Onyari J (1987)The concentration of heavy metals: Mn, Fe, Cu, Zn, $\mathrm{Cd}$ and $\mathrm{Pb}$ in sediments and fish from the Winam Gulf of Lake Victoria and fish bought in Mombasa town markets. Kenya Journal of Sciences 8: 5-18
17. Achoka JD (1998) Levels of the physico-chemical parameters in the liquid effluents from Pan African paper mills at Webuye and in River Nzoia. PhD Thesis, Moi University, Kenya.

18. Brooks JT, Shapiro RL, Kumar L, Wells JG, Phillips-Howard PA, et al. (2003) Epidemiology of sporadic bloody diarrhea in rural Western Kenya. American Journal of Tropical Medicine 68: 671-677.

19. Brooks JT, Ochieng JB, Kumar L, Okoth G, Shapiro RL, et al. (2006) Surveillance for bacterial diarrhea and antimicrobial resistance in rural western Kenya, 1997-2003. Clin Infect Dis 43: 393-401.

20. Onyango DM, Wandili S, Kakai R, Waindi EN (2009) Isolation of Salmonella and Shigella from fish harvested from the Winam Gulf of Lake Victoria, Kenya. $\mathrm{J}$ Infect Dev Ctries 3: 99-104.

21. Onyuka JH, Kakai R, Onyango DM, Arama PF, Ofulla VO (2011) Prevalence and Antimicrobial Susceptibility Patterns of Enteric Bacteria Isolated from Water and Fish in Lake Victoria Basin of Western Kenya. International Journal of Biological and Medical Sciences 1: 1 .

22. Odada EO, Olago DO, Bugenyi F, Kulindwa K, Karimumuryango J, et al. (2003) Environmental assessment of East African Rift Valley Lakes. Aquatic Sciences 65: 254-271.

23. Njuru PG (2001) An overview of the present status of Water Quality of Lake Victoria, Kenya: A limnological perspective. Ministry of Environment and Natural Resources, LVEMP Water Quality Component. pp: 1-11.

24. Tole MP, Jenipher MS (2001) Concentrations of Heavy metals in Water, Fish and Sediments of the Winam Gulf, Lake Victoria, Kenya. Lake Victoria Fisheries: Status, Biodiversity and Management 1: 1-9.

25. Ogoyi DO, Mwita CJ, Nguu EK, Shiundu PM (2011) Determination of heavy metal content in water, sediment and microalgae from Lake Victoria, Eas Africa. The Open Environmental Engineering Journal 4: 156-16.

26. Nicholson SE (1996) A review of climate dynamics and climate variability in Eastern Africa. In: The Limnology, Climatology and Palaeoclimatology of East African Lakes: 1996. In: Johnson TC and Odada EO (eds). Gordon and Breach Publishers, London. pp: 25-56.

27. Kenya National Bureau of Statistics (2010) The 2009 Kenya population and housing census. Volume $1 \mathrm{~A}$

28. American Public Health Association (APHA) (2005) Standard methods fo examination of water and wastewater, 21st edition. American Public Health Association, American Water Works Association and Water Environment Federation, Washington, DC

29. Adong FG (2001) Laboratory methods manual, analytical work instruction. Volume 1.

30. Yuan Y, Hall K, Oldham C (2001) A preliminary model for predicting heavy metal contaminant loading from an urban catchment. Sci Total Environ 266: 299-307.

31. Cappuccino J, Sherman N (2007) Microbiology- A laboratory manual (8th edn) Benjamin-Cummings Publishers Co. Inc., New York. pp: 137-149.

32. Bezuidenhout CC, Mthembu N, Puckree T, Lin J (2002) Microbiological evaluation of the Mhlathuze River, Kwazulu-Natal (RSA). Water SA 28: 281286.

33. UNICEF (2002) Official summary, the State of the World Children. p: 2.

34. Standing Committee of Analysts (2002) The microbiology of drinking water Part 1- Water quality and public health methods for the examination of waters and associated materials. Environment Agency.

35. World Health Organization (2006) Guidelines of drinking water quality.

36. Ochumba PBO, Kibaara DI (1989) Observations on blue- green algal blooms in the open waters of Lake Victoria, Kenya. African Journal of Ecology 27: 23-34.

37. Scannell PW, Jacobs LL (2010) Effects of Total Dissolved solids on aquatic organisms. In Alaska Department of Fish and Game: Division of habitat and restoration. Technical Report No. 01-06.

38. Patil G, Ahmed I (2011) Heavy metals contamination assessment of Kahargaon dam water near Chhindwara City. ActaChim Pharmaceutical Indica. pp: 7-9.

39. Camargo JA, Alonso A (2006) Ecological and toxicological effects of inorganic nitrogen pollution in aquatic ecosystems: A global assessment. Environ Int 32 831-849. 
Citation: Ouma SO, Ngeranwa JN, Juma KK, Mburu DN (2016) Seasonal Variation of the Physicochemical and Bacteriological Quality of Water from Five Rural Catchment Areas of Lake Victoria Basin in Kenya. J Environ Anal Chem 3: 170. doi:10.41722380-2391.1000170

40. Patrick L, William A (2011) Water Chemistry: an Introduction to the Chemistry of natural and Engineered Aquatic Systems. 1st edn. Oxford University Press, USA.

41. Ngodhe SO, Raburu PO, Achieng A (2013). The impact of water quality on species diversity and richness of macroinvertebrates in small water bodies in Lake Victoria Basin, Kenya. Journal of Ecology and the Natural Environment 6: $32-41$.

42. Akan JC, Abdulrahman FI, Dimari GA, Ogugbuaja VO (2008) Physicochemical determination of pollutants in wastewater and vegetable samples along the Jakara wastewater channel in Kano Metropolis Kano State, Nigeria. European Journal of Scientific Research 23: 122-133.

43. Irshad M, Malik N, Khan T, Faridullah M (2011) Effect of solid waste on heavy metal composition of soil and water at Nathiagali-Abbottabad. Department of Environmental Sciences, COMSATS Institute of Information Technology, Abbottabad, Pakistan.

44. Ho KC, Chow YL, Yau JT (2003) Chemical and microbiological qualities of The East River (Dongjiang) water, with particular reference to drinking water supply in Hong Kong. Chemosphere 52: 1441-1450.
45. Shanmugam $\mathrm{P}$, Ahn YH (2007) New atmospheric correction technique to retrieve the ocean colour from Sea WiFS imagery in complex coastal waters. Journal of Optics A: Pure and Applied Optics 9: 511-530.

46. Roohul A, Syed SA, Zubair A, Jabar ZKK (2012) Microbial analysis of drinking water and water distribution system in new urban Peshawar. Current Research Journal of Biological Science 4: 731-737.

47. Environmental protection agency (EPA) (2012) Conductivity. In Water Monitoring and assessment.

48. Onganga O, Righa M (2004) Dynamics of sewage spillage and storm water pollution on Lake Victoria Basin- A case study of Kisumu municipality.

49. Banadda N (2011) Characterization of non point source pollutants and theirdispersion in LakeVictoria: A case study of Gaba landing site in Uganda. African Journal of Environmental Science and Technology 2: 73-79.

50. Madema GJ, Shaw S, Waite M, Snozzi M, Morreau A, et al. (2003) Catchment characterization and source water quality. In Assessing Microbial safety of drinking water: Improving approaches and methods (Dufour A, Snozzi M and Koster W, et al. editions). WHO OECD, London 111: 158 